\title{
The uniqueness of twin loss and grief
}

\section{Joan M Creed DNP, RN}

University of South Carolina College of Nursing, Columbia, South Carolina

jcreed@mailbox.sc.edu

Keywords: twin loss, sibling loss, grief, bereavement, coping strategies

\section{Implications for practice}

- With little in the literature on adult twin death and grief, further research on identifying and testing interventions is necessary.

- The birth rate for twins has increased, thus the death rate of adult twins will also increase. Practitioners should be ready to address the needs of this population during their loss and grief.

\section{Background}

My identical twin died unexpectedly at 66 years of age following a diagnostic test without any problems during the procedure. However, she collapsed later that day and died within hours. I had many losses in my life, including my father and a brother, both expected, but this loss was overwhelming. Her unanticipated death left me feeling lost, devastated, and empty, feelings which were more intense than any previous loss. I felt there was a hole in my heart that I could never fill. I received support from one friend who had lost her identical twin many years ago. She told me she

\section{Abstract}

Loss of a twin unexpectedly in adulthood can leave the remaining twin feeling lost, devastated, and empty. The surviving twin can question the normalcy of these feelings and their response to the grief experience as compared to other losses. A literature review on adult twin loss followed by a review on sibling loss produced a sparse amount of information relevant to my questions. Both reviews centered around losses in childhood with little evidence of support for losses during adulthood. Guidance to assist with coping after this type of loss did not reveal specific coping strategies for the twinless twin. The coping strategies identified may be valuable for any person in their grieving process. The unique loss may benefit from future research on the most effective coping strategies. Grief therapists need further resources specific to singleton grief. Further research and clinical work would improve grief experiences during adult twin loss.

had similar feelings, and some continue to this day. I wondered if adult twin loss was different from grief with other family deaths. I questioned if my feelings were normal or not, and if not, how was I to cope and heal. How could I live without her? She had always been in my life since birth. Plus, I was concerned if what happened to my sister physically may be something that could affect me, my daughter, granddaughters, and future 
generations. I had many questions and feelings. Therefore, this paper aims to summarize current literature on grief and loss due to adult twin death and provide insight and strategies that may help others deal with twin and sibling loss.

\section{Insights from literature review on twin loss}

I wanted to find out if experiences like mine were available in the scientific literature. I searched the Gumulative Index to Nursing and Allied Health Literature (CINAHL) using bereavement, loss, grief, twins, identical twins, and adult twins. Most of the literature centered around the loss of a twin in utero, at birth, or as a young child. I found 14 articles written in the latter 1900s and early 2000s that related to my area of interest and mirrored my feelings and questions (Segal, 2019; Rosendahl et al, 2013; McIlroy, 2010; Segal, 2009; Tomassini et al, 2003; Segal et al, 2002; Segal \& Blozis, 2002;

Withrow \& Schweibert, 2005; Macdonald, 2002; Segal \& Ream, 1998; Woodward, 1988; Segal et al, 1995; Segal \& Bouchard, 1993; Nichols \& Bibro, 1966). Four topics provided insight into my experience. These topics included the closeness of the relationship between twins, the uniqueness and difference of the twin grief experience, the co-twin reaction to a sudden loss, and twin responses to grief inventories.

The closeness of the relationship between twins develops early in life and helps them avoid loneliness (Withrow \& Schwiebert, 2005). Their higher level of closeness is related to the number of years together before leaving home and how often they are in contact after they leave (Tomassini, et al, 2003). Monozygotic twins have significantly higher social closeness ratings than dizygotic twins related to shared life events and close companionship (Segal et al, 1995). With the death of the twin, this bond and closeness are permanently interrupted. The remaining twin must begin to identify as a singleton and move from an identity that included another to one that is only self. For me, I had often wondered what it would be like to be a singleton. Now that I was one, I did not like it. It did not feel right for me; it was not who I was. I remembered that grade school was our first significant separation, and we were anxious, not knowing if the other one was okay. Along with our parents, we cried every day; the teachers and administrators were apprehensive and did not know what to do.
After a parent-teacher conference, everyone agreed that we could get up any time during school to go to the door and check on our twin; it did not matter what was going on. For the next two weeks, we were up and down all the time; then, our trips slowly dwindled to none once we realized the other twin was fine.

I found that the twin grief experience was unique more profound and enduring than with other losses (Macdonald, 2002; Segal et al, 1995; McIlroy, 2011; Rosendahl et al, 2013) and the effect is more lasting than the effects of losing a non-twin relative (Segal \& Ream, 1998; Woodward, 1988). The loss of a healthy twin was associated with increased grief of the remaining co-twin (Segal \& Blozis, 2002). Twins experience a different type of loss than singletons (Withrow \& Schwiebert, 2005), and the grieving process for the surviving twin is distinct from that of other grieving individuals (McIlroy, 2011). I did not separate monozygotic twin loss from dizygotic twin loss. Some research suggests differences between these losses (Woodward, 1988; Segal \& Ream, 1998). Although the most precise method to determine the zygosity of twins is through a blood diagnosis and DNA testing, I did not have the option for this determination. Rather, I used the rules for the diagnosis of zygosity questionnaire established by Nichols and Bilbro (1988) to determine my zygosity. I fit with the criteria for the monozygotic twin including same hair and eye color, same height and weight, and occasionally mistaken identity by some family members, friends, and teachers.

The death of a co-twin is an emotionally distressful experience (Rosendahl et al, 2013). Much of my life, my twin and I shared birthday activities, parties, trips, and the same meal. As adults, we took special birthday trips together, but now I no longer had someone to share them with me. Thus, the reaction of the co-twin to a sudden loss resonated with me. Sudden loss does not provide individuals with adequate opportunities to prepare for an unexpected death. The unforeseen loss of a twin results in higher grief intensity and less favorable quality of life during the first one to two months following the loss (Segal \& Blozis, 2002). My previous family losses included a brother and my father, both expected losses; thus, I was better prepared and more in control when I experienced them. In hindsight, had these other losses been unexpected, my grief experience and reactions would have been very different. The sudden and 
unexpected loss of my sister caught me unaware and unprepared for the grief experience; I was not ready for it, nor did I want to be. I remembered the time she lived with my family for several months. She was having some personal difficulties and expressed to me that no one would come to her funeral. I was surprised and responded by saying, 'I won't be there'. She looked horrified. I replied, 'I want to die first because I cannot handle you dying first'. But that is what happened. Ironically, her church memorial service was standing room only.

The results of twin scores on grief inventories provided insight into the distinct experience of twin grief. Twins scored higher on bereavement scales than other individuals (Segal \& Bouchard, 1993; Segal et al, 1995; Segal \& Ream, 1997; Segal et al, 2002). Monozygotic twins scored higher than dizygotic twins on 6 of 8 scales on the Grief Experience Inventory (Segal et al, 2002). I have not taken any of these inventories; it may be interesting to review future information and data.

\section{Insights from literature review on sibling loss}

The literature on the loss of a sibling focused on childhood loss with little attention to this loss during adulthood. I found 22 articles, but only five were relevant to my interest, reinforcing the paucity of literature on adult bereaved siblings and interventions (Cohen \& Katz, 2015; Halliwell \& Franken, 2016; Bolton et al, 2016; Wright, 2016; Funk et al, 2018). The loss of a sibling was considered the loss of a lifelong friend, confidant, companion, and connection to memories (Wright, 2018; Halliwell \& Franken, 2016; Cohen \& Katz, 2015). Sibling mourners are considered unique and seen as the forgotten mourners (Cohen \& Katz, 2015; Halliwell \& Franken, 2016; Wright, 2016; Funk et al, 2018). Negative outcomes of sibling loss were predominant (Funk et al, 2018; Bolton et al, 2016), but positive outcomes were identified (Cohen \& Katz, 2015; Halliwell \& Franken, 2016). Storytelling and visiting the gravesite helped the grieving sibling cope with the loss (Halliwell \& Franken, 2016). I tell many stories about our escapades, including a Christmas when we gave our mom a book, Sex after Sixty, with all blank pages and wrote a message inside from an imaginary boyfriend. Mom's reaction was hysterical, so we continued this tradition for years afterward. While
I have these memories, closure has still been hard. I did not see my sister's body after her death, and there is no grave for me to visit as she was cremated. Instead, I have special objects in my house, such as pottery made by her, that helps me remember her and say goodbye.

The scientific literature had minimal information on the experience of twin loss but did reinforce that my experience, while unique, included common elements. These elements included unanticipated loss, fear of the unknown, being a singleton, and loss of a special relationship. In addition to these common elements, I was also dealing with the unknown. Her death resulted from blood clots, but the underlying medical condition was not identified; she was cremated before an autopsy was performed. I completed genetic counseling a couple of months after her death as I searched for answers. Two uncertain results suggested a possible increase risk of some female cancers. I discussed these results and potential surgery with my gynecologist but did not make a final decision. Thus, some questions will never be answered; I have accepted this reality. Several months later, when I faced cancer surgery, I was terrified that I would have blood clots and not survive.

\section{Coping}

Since my twin loss was different from previous family losses, I found my coping was different as well. I searched for guidance to assist in resolving my grief. I found little specific information. Therefore, I wanted this article to provide insight into twin loss and coping skills for those experiencing a similar loss. I searched for coping methods that I believed would be helpful to myself and others. Conventional approaches such as talking to others, taking care of yourself and accepting your feelings, celebrating their life, planning for grief triggers, and seeking professional help sustain many as they navigate the grief process. Of these approaches, I found that talking to others, taking care of myself, and accepting my feelings were most valuable.

Creative strategies are also helpful. The active or passive use of writing, poetry, art, music, storytelling, scrapbooking, and journaling initiate reflection, which leads to making sense of feelings. All these methods improve mood, enhance mental health, and shift from a negative to a positive 
attitude (Heiney, 1995). Memory writing (Furnes \& Dysvik, 2013) provides the opportunity to write expressively and informally to increase awareness of experiences and memories. I found storytelling and journaling helpful; they allowed me to share about my sister and some of our exploits over our lifetime together.

Traditional face-to-face and online support groups are beneficial. Examples include Safe Place to Grieve (Smith, 2020), Grief Share (n.d.), and VeryWellMind (Morin, 2020). Twinless Twin Support Group International (2020) assists twins who have lost their twin through support, resources, and meetings. They maintain a large membership, newsletter, and crisis support and are organized at the national, state, and local levels. Their resources are numerous and include articles, books, and videos on several topics. The Lone Twin Network (2020) is a support group for twinless twins over 18 years of age, based in the United Kingdom, and has members around the world. Support is provided through a confidential Facebook group once membership is confirmed. Other potential resources include apps, podcasts, and memoirs that provide a personal perspective to assist moving forward in loss. Woodward (2010) uses personal stories of bereaved twins to illustrate their experiences and the dynamics of twinship, thus providing professionals the opportunity to develop more effective support for the lone twin. In her memoir, Morgan (2010) shares her journey of grief, healing, and moving forward culminating in working with other lone twins. In the memoir by Shawn (2012), he provides a personal account of his life and that of his autistic twin sister and the mystery of being bonded to someone who can never be understood.

Grief rituals meet the personal needs of an individual experiencing grief and are ways for individuals to channel and ventilate feelings, support healthier feelings, attitudes, and beliefs, make sense of the grief experience, and accept the loss (Sas \& Coman, 2016). Honoring, letting go, and transformation through these rituals allows one to bring together memories to include in their future and move forward in grief and life. I have given thought to grief rituals but have not participated in any other than her memorial service.

A person's faith and religion have played a part in grief and healing from pain for generations and will continue to do so. Reliance on a higher being with support from other believers, prayer, scripture, and reading books that offer comfort and hope provide encouragement and assistance. My strong Christian faith and prayer life reinforced my belief that she is in heaven with a new body and no pain or disease.

Taking care of physical and mental needs during times of stress, grief, and turmoil is vital for healing. Exercise, spending time in nature, mindfulness, meditation, yoga, and other techniques promote healing. For me, walking daily in the woods on our farm, reading, and gardening provided healing for both my physical and my mental health. I find it relaxing and therapeutic as I pick blueberries, muscadines, and other fruits and vegetables available in our garden. These activities provide time to reflect, work through problems and issues, and look ahead to the next steps in my life journey.

\section{Moving forward}

As I write this article, it is over a year since my sister's unexpected death. I am coping with life as a singleton; I still do not like it, nor feel it is who I am. Much to my surprise, six months after my sister's death, a lump was discovered on my routine screening mammogram, which subsequent diagnostic procedures confirmed as breast cancer. Thus, my journey of surgery, chemotherapy, radiation therapy and recovery began. My sister's death and the surrounding circumstances took a back seat as I confronted cancer treatment and all the associated stresses while teaching in the college of nursing. Using the knowledge and coping strategies that emerged from my grief and cancer experience, I make the most of each moment with a positive attitude, realizing the uncertainty of life.

\section{Conclusion}

Though the literature on adult twin loss is scant, there is documentation on the uniqueness of the experience. Further research is needed to determine the most effective coping mechanisms that would promote grieving from this unique loss (Withrow \& Schwiebert, 2005). Grief therapists need further resources specific to singleton grief. Additional research and clinical work would improve grief experiences during adult twin loss. 
Acknowledgment: The author appreciates the editorial assistance of Dr Sue Heiney in preparing this article.

\section{References}

Bolton J, Au W, Chateau D, Walld R, Leslie W, Enns J, Martens P, \& Katz L (2016) Bereavement after sibling death: A population-based longitudinal case-control study, World Psychiatry, 15, 59-66. https://doi.org/10.1002/wps.20293

Cohen, O \& Katz M (2015) Grief and growth of bereaved siblings as related to attachment style and flexibility. Death Studies, 39, 158-164.

https://doi.org/10.1080/07481187.2014.923069

Funk A, Jenkins J, Astroth K, Braswell G \& Kerber C (2018) A narrative analysis of sibling grief. Fournal of Loss and Trauma, 23(1), 1-14.

https://doi.org/10.1080/15325024.2017.1396281

Furnes B \& Dysvik E (2013) Experiences of memorywriting in bereaved people. Bereavement Care 32(2), 65-73. https://doi.org/10.1080/02682621.2013.812817.

GriefShare (n.d.) [website] It hurts to lose someone: Find help at GriefShare. Available at:www.griefshare.org (accessed 5 October 2021).

Halliwell D \& Franken N (2016) 'He was supposed to be with me for the rest of my life': Meaning-making in bereaved siblings' online stories. Fournal of Family Connections, 16(4), 337-354.

https://doi.org/10.1080/15267431.2016.1194841.

Heiney S (1995) The healing power of story. Oncology Nursing Forum, 22(6), 899-904.

Lone Twin Network (n.d.) Lone Twin Network [website]. Retrieved fron https://lonetwinnetwork.org.uk/ (accessed 5 October 2021).

Macdonald A (2002) Bereavement in twin relationships: An exploration of themes from a study of twinship. Twin Research, 6(3), 218-226.

https://doi.org/10.1375/twin.5.3.218

McIlroy E (2011) One half living for two: Cross-cultural paradigms of twinship and twin loss. Omega, 64(1), 1-13. https://doi.org/10.2190/om.64.1.a.

Morgan M (2012) Beginning with the end: A memoir of twin loss and healing. Vantage Point.

Morin A (2020) The 7 best online grief support groups of 2020: Find a community that helps with loss. VeryWellMind. Available at: www.verywellmind.com/best-online-grietsupport-groups-4842333 (accessed 5 October 2021).

Nichols R \& Bilbro W (1966) The diagnosis of twin zygosity. Acta Genet.Stat.Med, 16(3), 265-275. https://doi.org/10.1159/000151973

Rosendahl S, Bulow P \& Bjorklund A (2013) Images of sorrow - experiences of losing a co-twin in old age. Scientific Research, 5(124), 64-73.

https://doi.org/10.4236/health.2013.512A009
Sas C \& Coman A (2016) Designing personal grief rituals: An analysis of symbolic objects and actions. Death Studies, 40(9), 558-569.

https://doi.org/10.1080/07481187.2016.1188868

Segal N (2019) Evolutionary perspectives on the loss of a twin. In TK Shackelford and V Ziegler-Hill (eds) Evolutionary Perspectives on Death (25-36). Springer Nature.

Segal N (2009) Suicidal behaviors in surviving monozygotic and dizygotic co-twins: Is the nature of the co-twin's cause of death a factor? Suicide and Life-Threatening Behavior, 39(6), 565-575 https://doi.org/10.1521/suli.2009.39.6.569

Segal N \& Blozis S (2002) Psychobiological and evolutionary perspectives on coping and health characteristics following loss: A twin study. Twin Research, 5(3), 175-187.

https://doi.org/10.1375/136905202320227835.

Segal N \& Bouchard T (1993) Grief intensity following the loss of a twin and other relatives: Test of kinship genetic hypotheses. Human Biology, 65(1), 87-105. Available at www.jstor.org/stable/41464364 (accessed 5 October 2021).

Segal N \& Ream S (1998) Decrease in grief intensity for deceased twin and non-twin relatives: An evolutionary perspective. Personality and Individual Differences, 25(2), 317-325. https://doi.org/10.1016/S0191-8869(98)00050-6.

Segal N, Sussman L, Marelich W, Mearns J \& Blozis S (2002) Monozygotic and dizygotic twins' retrospective and current bereavement-related behaviors: An evolutionary perspective. Twin Research, 5(3), 188-195.

https://doi.org/0.1375/twin.5.3.188.

Segal N, Wilson S, Bouchard T \& Gitlin D (1995)

Comparative grief experiences of bereaved twins and other bereaved relatives. Personality and Individual Differences, 18(4), 511-524.

Shawn A (2012) Twin: A memoir. Viking.

Smith C (2020) A safe place to grief (Self-guided online grief program). [Blog]. Available at:

https://clairebidwellsmith.com/online-grief-program/ (accessed 5 October 2021).

Tomassini C, Juel K, Holm V, Skytthe A \& Christensen K (2003) Risk of suicide in twins: 51 year follow up study. British Medical Fournal, 327(7411), 373-374.

https://doi.org/10.1136/bmj.327.7411.373

Twinless twins. (2020) Twinless twins support group international. [website]. Available at: www.twinlesstwins.org/ (accessed 5 October 2021).

Withrow R \& Schweibert V (2005) Twin loss: Implications for counselors working with surviving twins. Fournal of Counseling and Development, 83, 21-28.

Woodward J (2010) The lone twin: A study in bereavement and loss. Free Association Books.

Woodward J (1988) The bereaved twin. Acta Geneticae

Medicae et Gemellologiae, 37(2), 173-180.

https://doi.org/10.1017/s0001566000004098.

Wright P (2016) Adult sibling bereavement: Influences, consequences, and interventions. Illness, Crisis, and Loss, 24(1), 34-45 https://doi.org/10.1177/1054137315587631. 